\title{
Temporal Analysis of Changes in Anthropogenic Emissions and Urban Heat Islands during COVID-19 Restrictions in Gauteng Province, South Africa
}

Special Issue:

Special Issue on COVID-19 Aerosol Drivers, Impacts and Mitigation (XVII)

\author{
Lerato Shikwambana $^{1,2^{*}}$, Mahlatse Kganyago ${ }^{1,2}$, Paidamwoyo Mhangara² \\ ${ }^{1}$ Earth Observation directorate, South African National Space Agency, The Enterprise Building, \\ Mark Shuttleworth Street, Pretoria 0001, South Africa \\ ${ }^{2}$ School of Geography, Archaeology and Environmental Studies, University of the \\ Witwatersrand, Johannesburg 2050, South Africa
}

\section{OPEN ACCESS}

Received: July 24, 2020

Revised: May 5, 2021

Accepted: May 26, 2021

${ }^{*}$ Corresponding Author:

Ishikwambana@sansa.org.za

\section{Publisher:}

Taiwan Association for Aerosol Research

ISSN: $1680-8584$ print

ISSN: 2071-1409 online

(c) Copyright: The Author(s). This is an open access article distributed under the terms of the Creative Commons Attribution License (CC BY 4.0), which permits unrestricted use, distribution, and reproduction in any medium, provided the original author and source are cited.

\section{ABSTRACT}

Anthropogenic emissions are significant drivers of temperature rises in major urban areas across the globe. Waste heat and exhaust emissions from motor vehicles and industrial combustion cause the warming of cities, resulting in microclimates' changes. Recently, national lockdown regulations restricting movement and socio-economic activities to curb the spread of a novel COVID-19 and the associated deaths have been implemented in various countries worldwide. Consequently, these unprecedented restrictions resulted in reductions in traffic volumes and industrial activities in most urban areas across the world. Thus, it was hypothesised that these reductions in traffic congestion and industrial activities in cities would reduce both air pollutants and thermal radiation. Using multisource data from Sentinel-5P, MERRA-2, and MODIS, this study assessed the short-term trends in emissions and land surface temperature in South Africa's economic hub, i.e., Gauteng Province. Mann-Kendall (MK) and Sequential Mann-Kendall (SQMK) trend analysis were used to characterise trends in $\mathrm{CO}, \mathrm{SO}_{2}, \mathrm{SO}_{4}$, long-wave radiation (LWR), and land surface temperature (LST) at periods corresponding to various lockdown restrictions. The results showed a significant decline in atmospheric pollutants at Level-5 lockdown restrictions, followed by an abrupt increase as the regulations were eased to Level-4 lockdown. Similarly, LST and surface urban heat island (SUHI) reduced when compared to the previous year. Therefore, the lockdown restrictions provided an experimental scenario in which pollutants could be drastically reduced, thus accentuated the human impact on microclimates.

Keywords: Lockdown, COVID-19, Emissions, Nitrogen dioxide, Sentinel-5P

\section{INTRODUCTION}

Anthropogenic emissions and air pollution are significant drivers of temperature rises in major urban areas worldwide (Taha, 1997; Ryu and Baik, 2012; Ma et al., 2017). Waste heat and exhaust emissions from motor vehicles and industrial combustion cause warming of cities resulting in changes in microclimates urban areas (Schiano-Phan et al., 2015; Soltani and Sharifi, 2017). The marked increase in urban temperature compared to the neighbouring non-urban areas is known as the urban heat island effect (Oke, 1982; Gallo et al., 1993). Several factors are known to impact the urban heat island. These include anthropogenic heat, air pollution, surface geometry, thermal characteristics of urban artificial fabrics, surface geometry, reduced evaporation, increased heat storage, increased net radiation, reduced convection and surface waterproofing (Grimmond, 2007; Shahmohamadi et al., 2011; Soltani and Sharifi, 2017). Emission of Carbon dioxide, water vapour, and particulates into the atmosphere warms ambient air in urban environments through the reduction of incident flux of short-wave radiation and re-emission of long-wave infrared radiation from the urban surface and subsequent absorption of long-wave radiation from the urban surface (Ramanathan and Feng, 2009). A combination of air pollution and anthropogenic 
heat produced by human activities due to transportation, human metabolism, heating, and cooling affect urban temperature conditions through the heat transfer processes that influence the formation of urban heat islands. The complex interaction of anthropogenic heat with the environment are succinctly simplified by Oke (1988).

The Urban Heat Island (UHI) phenomena have been analysed in many cities globally and constitute of three main segments classified as canopy UHI, boundary-layer UHI, and surface UHI (Azevedo et al., 2016). Specifically, the surface UHIs (SUHIs) are commonly studied for UHIs as they can be detected by land surface temperature (LST) measurements from satellites. It directly affects the air temperature in the canopy layer by energy exchange. Anthropogenic factors such as industrial heat emissions, heating, transport, or air conditioning are recorded to affect surface UHI significantly (Wang et al., 2018; Shi et al., 2019). These elevated urban temperatures have detrimental effects on human health and energy consumption from increased indoor air conditioning (Priyadarsini, 2009; Shahmohamadi et al., 2011; Arifwidodo and Chandrasiri, 2015). It is well recorded that high temperature causes heat stress and increases the risks of dehydration, heatstroke, and hyperthermia associated with heatwaves (Hifumi et al., 2018; Leyk et al., 2019). Studies reveal that during favourable weather conditions, i.e., no cloud cover and stable wind conditions, urban temperatures tend to be more elevated by at least 6 to $11^{\circ} \mathrm{C}$ compared to the rural sites (Suomi, 2018) (https://www.britannica.com/science/urban-climate). The utility of the earth observation satellites to efficiently measure atmospheric aerosols and land surface parameters that influence UHI formation has been widely used in a multitude of UHI studies.

Thermal space-borne data from sensors such as Landsat Thematic Mapper (TM), Landsat Enhanced TM (ETM+), Landsat 8 Thermal Infrared Sensor (TIRS), ASTER, Advanced Very HighResolution Radiometer (AVHRR), and Moderate Resolution Imaging Spectroradiometer (MODIS) have been widely used to retrieve LST (Zha et al., 2003; Chen et al., 2006; Liu and Zhang, 2011; Tsou et al., 2017). Thermal Infrared measurements from optical satellites are often constrained by cloud cover and low temporal resolution. Modern microwave space-borne instruments can provide near-surface air temperature at a high temporal frequency and penetrate through the cloud cover. Before its demise in October 2011, the Advanced Microwave Scanning RadiometerEarth observing system (AMSR-E) onboard the Aqua satellite collected measurements on the land surface and boundary layer (Gao et al., 2007; Zhao et al., 2017). Sentinel-5P from the European Commission's Copernicus program and long-term missions such as MODIS are invaluable for measuring atmospheric and surface parameters that influence the UHI. Sentinel-5P has been limitedly explored for characterising atmospheric pollutants. In contrast, MODIS remains the main sensor for frequent thermal infrared measurements, suitable for studying short-term changes.

A global pandemic is known as coronavirus disease 2019 (COVID-19) started from Wuhan, China, in December 2019 has affected many countries internationally (Harapan et al., 2020). It is widely accepted that the COVID-19 pandemic is possibly the worst global public health crisis since the influenza pandemic in 1918 (Beach et al., 2020). The infectious nature of the COVID-19 and the associated high death rates forced most governments globally to institute lockdowns that control the rapid spread of this deadly disease (Haldar and Sethi, 2020). The lockdown measures resulted in various levels of restrictions on movement, trade, transport, and mining operations and industries' closures for periods ranging from a few weeks to several months. Governments' unprecedented control measures resulted in low traffic volumes and low industrial combustion in most urban areas in some countries, thus resulting in a reduction in both air pollution and anthropogenic heat (Metya et al., 2020; Jain and Sharma, 2020). Therefore, this study's objective was to assess the trends of air pollution in the Gauteng Province, Republic of South Africa (RSA) over the lockdown period and the subsequent changes in urban temperature using multisource data. Specifically, Sentinel-5P was used to assess the temporal trends in atmospheric pollutants such as $\mathrm{NO}_{2}, \mathrm{SO}_{4}$, and $\mathrm{CO}$, while MODIS data were used to assess LST and surface urban heat islands (SUHI) in Gauteng province.

\section{STUDY AREA}

South Africa $\left(30.56^{\circ} \mathrm{S}, 22.94^{\circ} \mathrm{E}\right)$ has nine provinces with widely varying landscapes (Fairbanks et al., 2000), with the Gauteng province $\left(26.27^{\circ} \mathrm{S}, 28.11^{\circ} \mathrm{E}\right)$ having the smallest land area. 
However, Gauteng province has the biggest provincial economy generating over a third of South Africa's gross domestic product (GDP). As can be expected, Gauteng is also the most populated among other provinces, constituting more than $26 \%$ (i.e., $15,488,137$ ) of South Africa's population. It is divided into three metropolitan municipalities; the City of Ekurhuleni, City of Johannesburg, and City of Tshwane Metropolitan Municipalities and two district municipalities, which are further subdivided into six local municipalities (see Fig. 1). Compared to other provinces (not shown in Fig. 1), Gauteng has more built-up area (consisting of impervious surfaces such as buildings, mines, and quarries). However, it also has large areas of cultivated lands and grasslands.

\section{METHODS}

\subsection{Atmospheric Emissions}

The Copernicus Sentinel-5P (Precursor) satellite was launched on October 13 2017, by the European Space Agency (ESA). The TROPOspheric Monitoring Instrument (TROPOMI) is an onboard sensor Sentinel-5P, which monitors the density of several atmospheric gases, aerosols, and cloud distributions that affect air quality and climate (Veefkind et al., 2012; Omrani et al., 2020). TROPOMI has full global coverage each day with an improved resolution of $\left(3.5 \times 7 \mathrm{~km}^{2}\right)$, which is 13 times better than the Ozone Monitoring Instrument (Theys et al., 2019). The comparison of these two instruments shows that the high spatial resolution of TROPOMI observations is adequate to monitor polluting emission sources at a city level (lalongo et al., 2020). The algorithms for sulfur dioxide $\left(\mathrm{SO}_{2}\right)$ retrieval are described by Theys et al. (2017). TROPOMI is operated in a non-scanning push-broom configuration, with an instantaneous field of view of $108^{\circ}$ and a measurement period of about $1 \mathrm{~s}$ (lalongo et al., 2020). Furthermore, TROPOMI has more spectral

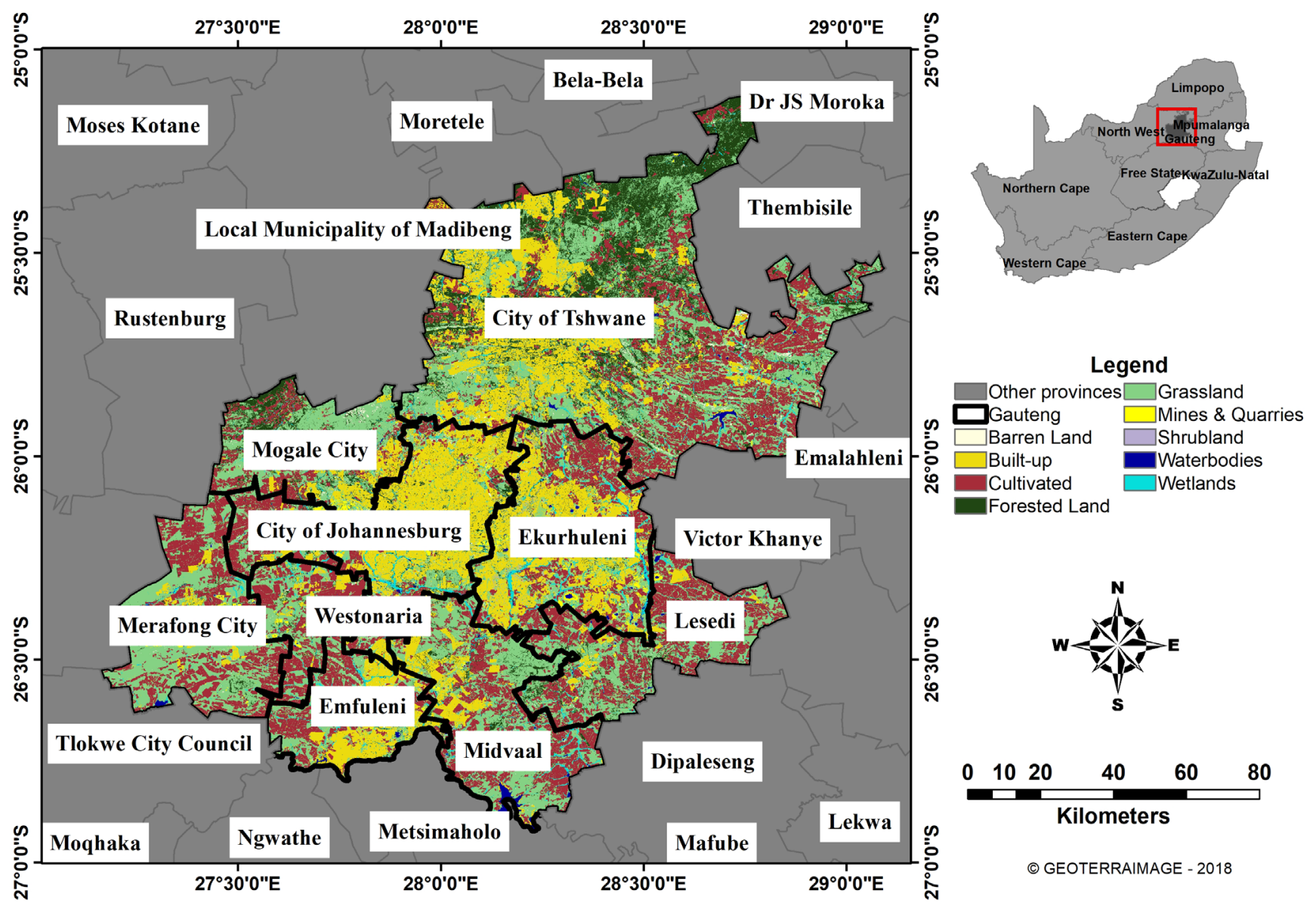

Fig. 1. Map of the Republic of South Africa showing the location of the nine provinces and the study area (Gauteng Province) is indicated by a red rectangle. Map of the Gauteng province showing the municipal boundaries and land cover. 
bands than previous sensors. It has ultraviolet and visible in the range (270-500 nm), near-infrared in the range (675-77 $\mathrm{nm})$, and short-wave infrared in the range (2305-2385 nm). A wide variety of these spectral bands allows TROPOMI to measure a broader range of atmospheric trace gases such as nitrogen dioxide $\left(\mathrm{NO}_{2}\right)$, ozone $\left(\mathrm{O}_{3}\right)$, sulfur dioxide $\left(\mathrm{SO}_{2}\right)$, methane $\left(\mathrm{CH}_{4}\right)$, and carbon monoxide (CO) (Omrani et al., 2020). For TROPOMI, quality-control has been performed before the analysis. A flag, namely quality assurance value (qa_value), for each ground pixel indicates the status and quality of the retrieval result, ranging from 0 (no output) to 1 (http://www.tropom i.eu/documents/level-2). Furthermore, when the TROPOMI OFFL level 2 tropospheric columns were compared with multi-axis DOAS (MAX-DOAS) data at 14 sites, it was found that TROPOMI tropospheric columns have a median negative bias of less than 50\% (Zhao et al., 2020). In this study, the focus is on the $\mathrm{SO}_{2}$, and $\mathrm{CO}$ OFFL level 2 tropospheric columns.

The nitrogen oxide $\left(\mathrm{NO}_{2}\right)$ tropospheric column density datasets are retrieved from the Ozone Monitoring Instrument (OMI). OMI uses hyperspectral imaging in a push-broom mode to observe solar backscatter radiation in the visible and ultraviolet. It is a nadir-viewing, wide-field-imaging UV and visible spectrometer designed to monitor ozone and other atmospheric species including aerosols. It can also distinguish between aerosol types, such as smoke, dust, and sulfates, and can further measure key air quality components such as $\mathrm{NO}_{2}, \mathrm{SO}_{2}$ and Bromine oxide (BrO) to name a few. A detailed description of OMI is discussed by Levelt et al. (2016). In this study, the focus is on the $\mathrm{NO}_{2}$ tropospheric column datasets.

The sulfate $\left(\mathrm{SO}_{4}\right)$ data were retrieved from the Modern-Era Retrospective analysis for Research and Applications, Version 2 (MERRA-2). MERRA-2 was introduced to replace and extend the original MERRA dataset (Rienecker et al., 2008; Rienecker et al., 2011), which ended in February 2016. It is produced using version 5.12.4 of the GEOS DAS. Gridded data are released at a $0.625^{\circ}$ longitude $\times 0.5^{\circ}$ latitude resolution on 72 sigma-pressure hybrid layers between the surface and $0.01 \mathrm{hPa}$. The bottom 32 layers are terrain following, while remaining model layers from 164 to $0.01 \mathrm{hPa}$ are constant pressure surfaces (Wargan et al., 2017). MERRA-2 assimilates bias-corrected AOD from the Moderate Resolution Imaging Spectroradiometer (MODIS) and the Advanced Very HighResolution Radiometer instruments (Buchard et al., 2017; Randles et al., 2017). More details on MERRA-2 can be found in Gelaro et al. (2017). Additionally, data for surface absorbed long-wave radiation was retrieved from MERRA-2.

\subsection{Land Surface Temperature (LST) and Surface Urban Heat Island (SUHI)}

Land Surface Temperature (LST) was derived from the Moderate Resolution Imaging Spectroradiometer (MODIS). Specifically, the MODIS 8-day Land Surface Temperature and Emissivity (MOD11.006) product from February 01 to May 31, 2019, and 2020, i.e., characterising the reference and Covid-19 years, respectively, were averaged over the study area for further analysis. MODIS LST product (i.e., MOD11A2.006) is an 8-day average of MOD11A1 LST in a grid of $1200 \times 1200 \mathrm{~km}$. Further details can be found in Wan (2014). In this study, day-time LST was used to characterize LST at periods: 01 February-26 March (i.e., before lockdown), 27 March-30 April (i.e., during Level-5 lockdown) and May 01-31 May (during Level-4 lockdown) (see Table 1 for description of various lockdown levels).

The averaged LST per lockdown period was used to compute the surface urban heat island (SUHI) intensity respectively. SUHI is calculated as a difference in LST between the urban (i.e., built-up) and rural (i.e., peripheral green spaces). For each pixel, SUHI intensity was calculated as follows:

SUHI intensity $=L S T_{\text {urban }}-\overline{L S T}_{\text {rural }}$

Table 1. Lockdown levels in South Africa during the global pandemic.

\begin{tabular}{llll}
\hline Lockdown level & Duration of lockdown & Number of days & Determination of levels \\
\hline 5 & 27 March 2020-30 April2020 & 35 & $\begin{array}{c}\text { High COVID-19 spread with a low health system } \\
\text { readiness } \\
\text { Moderate to a high COVID-19 spread with a low } \\
\text { to moderate health system readiness }\end{array}$ \\
\hline
\end{tabular}


where, $L S T_{\text {urban }}$ is the pixel-wise land surface temperature (LST) and $\overline{L S T}_{\text {rural }}$ is the mean LST over surrounding green spaces at the study area (Estoque and Murayama, 2017). The $\overline{L S T}_{\text {rural }}$ was extracted based on the 2018 National Land Cover (NLC) data from the South African Department of Environmental Affairs (accessible from: https://egis.environment.gov.za/sa_natio nal_land_cover_datasets). LST over Water bodies was excluded.

Furthermore, the spectral discrimination index (SDI, Eq. (1)) was used to determine the degree of observed differences between 2020 (i.e., COVID-19) and 2019 (i.e., reference) years.

$S D I=\frac{\left|\mu_{1}-\mu_{2}\right|}{\sigma_{1}+\sigma_{2}}$

where $\mu_{1}$ and $\mu_{2}$ denote the mean LST for 2020 (i.e., COVID-19 year) and 2019 (i.e., reference year), while $\sigma_{1}$ and $\sigma_{1}$ denote standard deviations for 2020 and 2019, respectively. SDI values greater than 1 indicate a higher degree of difference between the COVID-19 year (2020) and reference year (2019), while a value lower than 1 indicates no difference. Previously, the SDI has been used for spectral separability between different images and vegetation types (Kganyago et al., 2018).

\subsection{M-K and SQMK Trend Analysis}

The non-parametric Mann-Kendall (MK) test is generally used to detect monotonic trends in a series of environmental data, climate data, and hydrological data (Mann, 1945; Abghari et al., 2013; Pohlert, 2018). The MK test has several advantages, such as (1) its low sensitivity to abrupt breaks due to inhomogeneous time series (Tabari et al., 2011) and (2) its ability to consider the data distribution and cope with the outliers (Sonali and Kumar, 2013; Şen, 2017; Nashwan and Shahid, 2019). The MK test steps are presented in Appendix 2.

The Sequential Mann-Kendall (SQMK) test proposed by Sneyers (1991) is used for determining the approximate period of the beginning of a significant trend (Sneyers, 1997; Kganyago and Shikwambana, 2019). This test sets up two series, a progressive $u(t)$ and a retrograde (backward) series $u^{\prime}(t)$. If they cross each other and diverge beyond the specific threshold value, then there is a statistically significant trend. The point where they cross each other indicates the approximate period at which the trend begins (Mosmann et al., 2004). The threshold values used in this study are $\pm 1.96(p=0.05)$, with the crossing point indicating the change point for trends. The SQMK test steps are presented in Appendix 3.

\section{RESULTS AND DISCUSSION}

\section{1 $\mathrm{NO}_{2}$ Observations over RSA and Gauteng Province}

Fig. 2 shows the distribution of $\mathrm{NO}_{2}$ over RSA before and during the lockdown. Before the lockdown (see Fig. 2(a)), high $\mathrm{NO}_{2}$ tropospheric column values ranging from $7 \times 10^{15}$ to $9 \times 10^{15}$ $\mathrm{mol} \mathrm{cm} \mathrm{cm}^{-2}$ are observed in the Gauteng, Mpumalanga, and Limpopo provinces. These high values of $\mathrm{NO}_{2}$ can be attributed to both (1) emissions from the coal-powered stations for electricity generation and (2) motor vehicle emissions which make a substantial contribution to the boundary layer concentrations of $\mathrm{NO}_{2}$, especially upwind from the power stations. These areas have been reported as the hotspots of $\mathrm{NO}_{2}$ in RSA (Shikwambana et al., 2020). Shikwambana et al. (2020) further describe the dispersion of $\mathrm{NO}_{2}$ during various seasons. During Level-5 of the lockdown (see Fig. 2(b)), there is a slight reduction in the $\mathrm{NO}_{2}$ distribution over RSA hotspots; however, the Gauteng province has a notable decrease in the $\mathrm{NO}_{2}$ distribution and tropospheric column values ranging from $4 \times 10^{15}$ to $5 \times 10^{15} \mathrm{~mol}_{\mathrm{cm}} \mathrm{cm}^{-2}$ ). This decrease could be due to lesser demand for electricity due to the closure of industries and mines. Therefore, not all power stations were operating at full capacity. Furthermore, the reduction of motor vehicle emissions also had a large impact in the detection of lesser $\mathrm{NO}_{2}$.

Moreover, the power stations also used the lockdown period for maintenance; thus, only a few generating units were operating. A move to the Level-4 lockdown (see Fig. 2(c)) saw a steady increase in the $\mathrm{NO}_{2}$ tropospheric column values (back to the $8 \times 10^{15}$ and $9 \times 10^{15} \mathrm{~mol} \mathrm{~cm}^{-2}$ range) 
Before Lockdown $(01 / 02 / 20-26 / 03 / 20)$

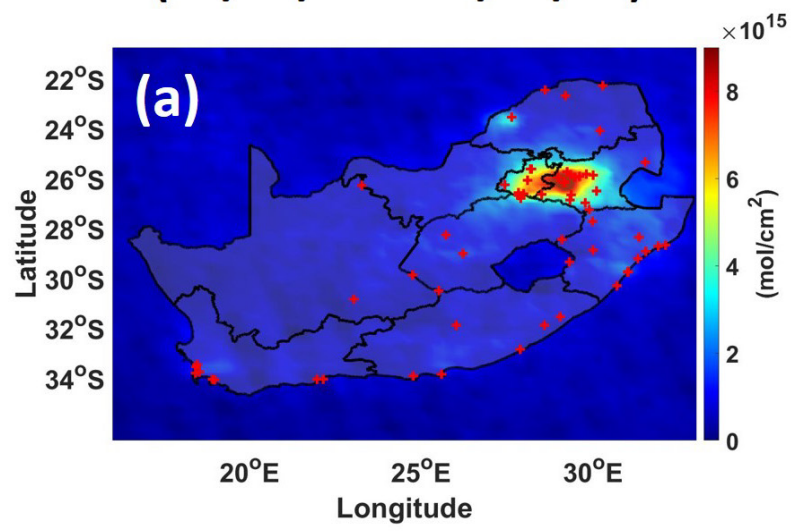

Level 4 Lockdown

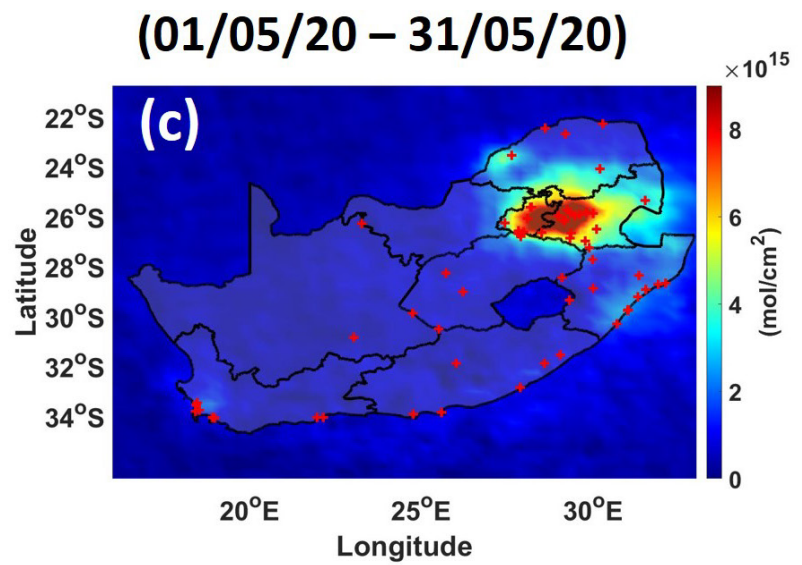

Level 5 Lockdown $(27 / 03 / 20-30 / 04 / 20)$

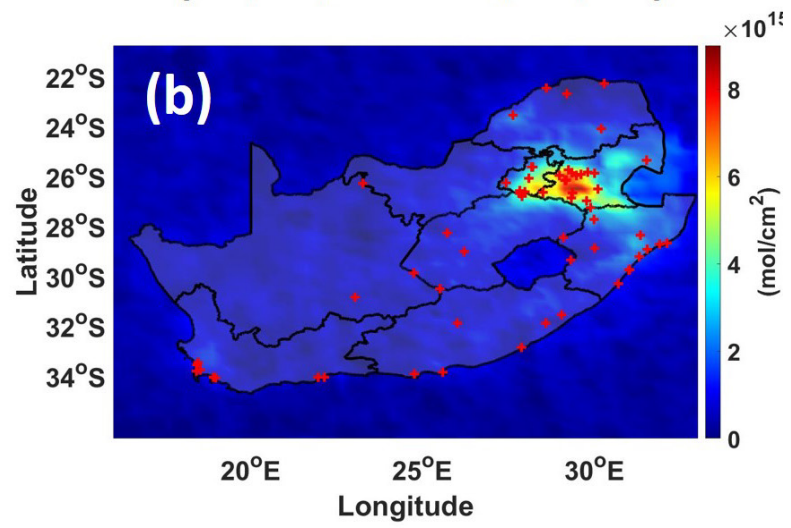

\section{South Africa \\ power stations}

Fig. 2. $\mathrm{NO}_{2}$ tropospheric column and distribution (a) before the lockdown, (b) during the lockdown Level 5 and (c) during the lockdown Level 4 over RSA observed by OMI.

and more extensive distribution of $\mathrm{NO}_{2}$ in the hotspot areas. The increase in the $\mathrm{NO}_{2}$ column density is due to the increase in generation units' operation as electricity consumption increased in Level-4, as seen in the Energy Transition in South Africa-The Power Sector in 2020 report.

Fig. 2 clearly shows that Gauteng is amongst the leading provinces in terms of $\mathrm{NO}_{2}$ distribution and total column density. Therefore, the $\mathrm{NO}_{2}$ distribution and total column density over the Gauteng Province's municipal boundaries, before and during the lockdown, are analysed further (see Fig. 3). Gauteng has Before the lockdown (see Fig. 3(a)), high $\left(0.00013 \mathrm{~mol} \mathrm{~m}^{-2}\right)$ to moderate $\left(0.00010 \mathrm{~mol} \mathrm{~m}^{-2}\right.$ and $\left.0.000078 \mathrm{~mol} \mathrm{~m}^{-2}\right)$ column density values are observed in Johannesburg, Ekurhuleni, Mid-Vaal and Emfuleni, and southern parts of Tshwane. In Johannesburg, Ekurhuleni and Tshwane, the primary source of $\mathrm{NO}_{2}$ is motor vehicle emissions, especially during high traffic peak periods. In the Mid-Vaal and Emfuleni areas, the primary source of $\mathrm{NO}_{2}$ is industrial and processing activities. These are industrial areas comprise of coal-fired power stations and chemical producing companies.

During Level-5 of the lockdown, there is a noticeable decline in the $\mathrm{NO}_{2}$ total column densities values in Johannesburg, Ekurhuleni and Tshwane. An approximate decline of $31 \%$ of $\mathrm{NO}_{2}$ in these areas is observed. This reduction is due to the decrease in motor vehicles on the road, closure of some factories, a drop in the coal-fired power station's operations, and the chemical producing companies. Most companies were dormant during 35 days of the Level-5 lockdown, with most people restricted to their homes. This has resulted in fewer vehicles on the road. However, during the 31 days of the Level-4 lockdown, an increase in the $\mathrm{NO}_{2}$ total column density values is observed (see Fig. 3(c)). Level-4 regulations allowed for more mobility and the opening of some 


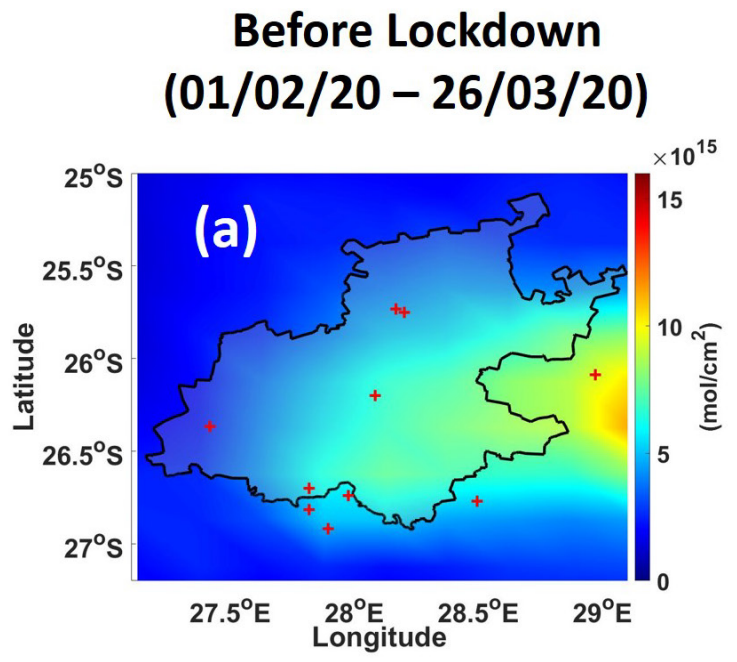

Level 4 Lockdown

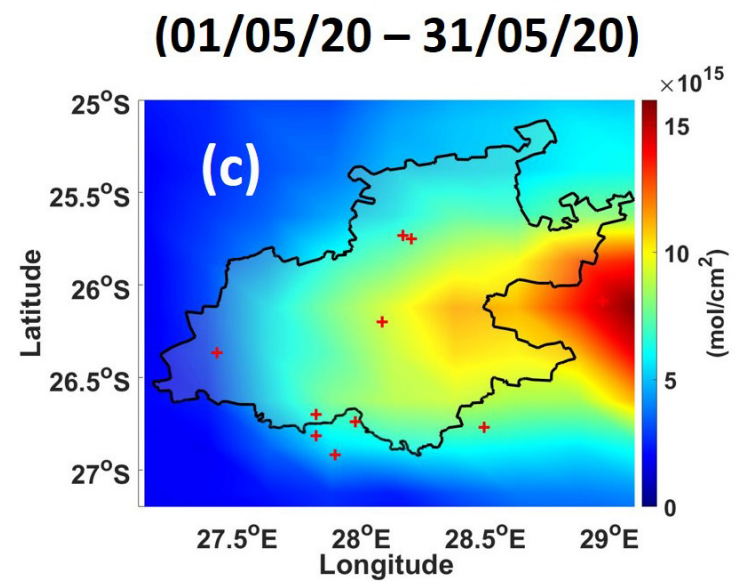

Level 5 Lockdown

$(27 / 03 / 20-30 / 04 / 20)$

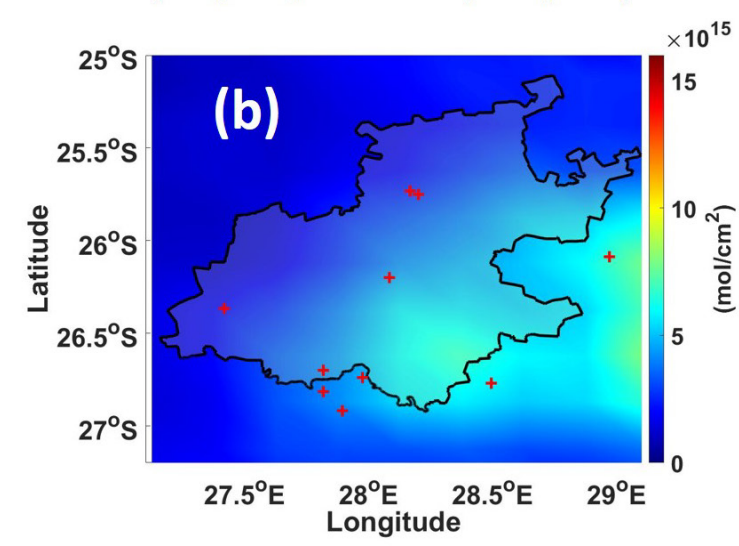

\section{$+\begin{aligned} & \text { South Africa } \\ & \text { power stations }\end{aligned}$}

Fig. 3. $\mathrm{NO}_{2}$ tropospheric column and distribution (a) before the lockdown, (b) during the lockdown Level 5 and (c) during the lockdown Level 4 over the Gauteng Province observed by OMI.

economically strategic companies. This led to the re-opening of most industries, thus increased mobility. Consequently, the number of vehicles on the road increased, thus increasing the emissions of $\mathrm{NO}_{2}$. Moreover, the re-opening of industries and their near full capacity operations led to more emissions.

\section{2 $\mathrm{SO}_{2}$ Observations over RSA and Gauteng Province}

Fig. 4 shows the distribution of $\mathrm{SO}_{2}$ over RSA before and during the lockdown. Before the lockdown (see Fig. 4(a)), $\mathrm{SO}_{2}$ hotspots are observed in the Limpopo, Mpumalanga, and Gauteng provinces. The primary sources of $\mathrm{SO}_{2}$ in these areas are coal-fired power stations (Pretorius et al., 2015; Girmay and Chikobvu, 2017; Shikwambana et al., 2020). Other sources of $\mathrm{SO}_{2}$ include the processing, manufacturing, mining, and smelter industries. Motor vehicle emissions also have a small $\mathrm{SO}_{2}$ contribution to the local total $\mathrm{SO}_{2}$ density (Pierson et al., 1978; Yasar et al., 2013). Extensive distribution of $\mathrm{SO}_{2}$ is observed from the hotspot areas. However, during the Level-5 lockdown period, a slight decrease in the distribution of $\mathrm{SO}_{2}$ is observed. This indicates lesser emissions of $\mathrm{SO}_{2}$ due to (1) a decrease in electricity production resulting from a lesser demand for electricity by the manufacturing, mining, smelters, and processing industries. (2) Lesser motor vehicles on the road also slightly contribute to the lower $\mathrm{SO}_{2}$, as observed. With the easing of the regulations from Level-5 to Level-4, an uneven distribution of $\mathrm{SO}_{2}$ is observed in most RSA. The sudden increase in the $\mathrm{SO}_{2}$ distribution is mainly due to the full operations of the coal-fired power stations and industries' resumption to their full capacities. This resulted in an increase in $\mathrm{SO}_{2}$ loading in the atmosphere. Interestingly, regions in RSA known to have less $\mathrm{SO}_{2}$ densities (namely, 
Before Lockdown
$(01 / 02 / 20-26 / 03 / 20)$

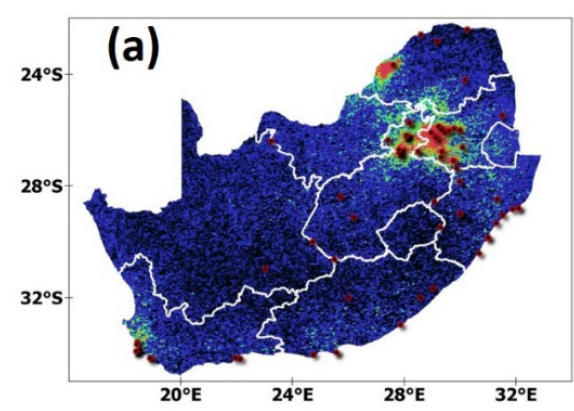

Level 4 Lockdown $(01 / 05 / 20-31 / 05 / 20)$

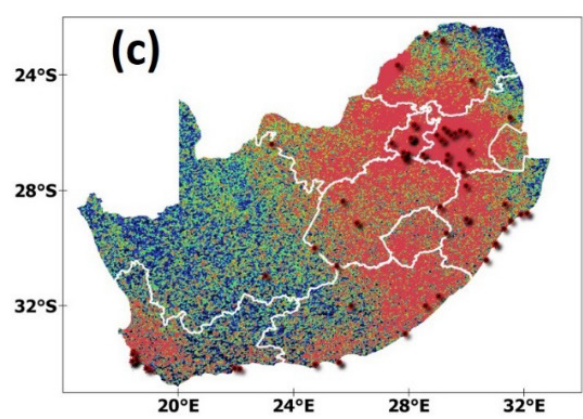

Level 5 Lockdown

$(27 / 03 / 20-30 / 04 / 20)$

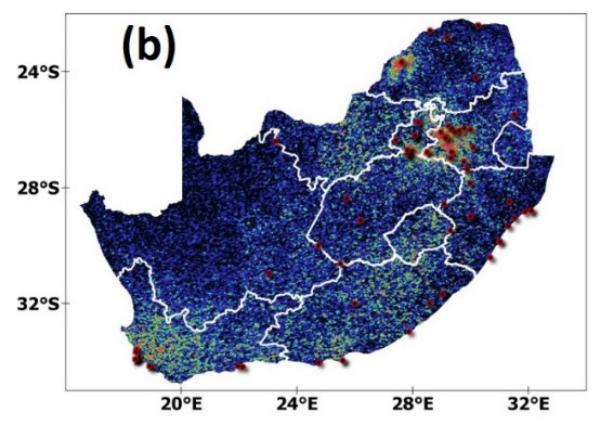

South Africa power stations

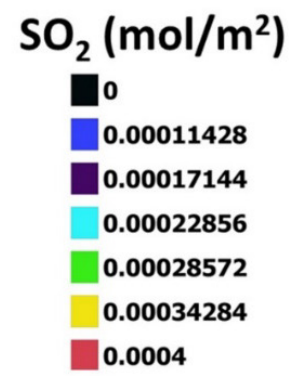

Fig. 4. $\mathrm{SO}_{2}$ total column density and distribution (a) before the lockdown, (b) during the lockdown Level 5 and (c) during the lockdown Level 4 over RSA.

the Western Cape and Eastern Cape provinces) suddenly experienced larger densities of $\mathrm{SO}_{2}$. The more stable condition of the atmosphere in the May period and the massive injection of $\mathrm{SO}_{2}$ in the atmosphere could be the main reason for the rapid dispersion of $\mathrm{SO}_{2}$ countrywide (Shikwambana et al., 2020).

The distribution of $\mathrm{SO}_{2}$ over the Gauteng Province before and during the lockdown is shown in Fig. 5. Before the lockdown restrictions, large values of the total column density $\left(0.0004 \mathrm{~mol} \mathrm{~m}^{-2}\right.$ and $0.00034 \mathrm{~mol} \mathrm{~m}^{-2}$ ) are observed in the central, eastern and southern parts of the Gauteng Province (see Fig. 5(a)). These are the regions with high emissions of $\mathrm{SO}_{2}$ from (1) the coal-fired power station in the south of Gauteng and (2) high traffic congestion in the central and eastern parts of Gauteng. However, after the Level-5 lockdown restrictions (see Fig. 5(b)), a noticeable drop in the $\mathrm{SO}_{2}$ column density $\left(0.00011-0.00017 \mathrm{~mol} \mathrm{~m}^{-2}\right)$ is observed in these hotspot areas, especially in the central and eastern parts of Gauteng. This is mainly from the reduction in traffic congestion. In southern Gauteng, the slight decrease in $\mathrm{SO}_{2}$ distribution was due to the limited operation of the coal-fired power stations. Upon the introduction of the Level-4 lockdown, large values of the $\mathrm{SO}_{2}$ column density $\left(0.0004 \mathrm{~mol} \mathrm{~m}^{-2}\right)$ are observed in the entire Gauteng Province (see Fig. 5(c)). The meteorological conditions in this period are suspected of having aided the dispersion of $\mathrm{SO}_{2}$ in the region (Shikwambana et al., 2020). More importantly, the recommencement of mobility (i.e., motor vehicles), the coal-fired power station's full operations, and industries increased the $\mathrm{SO}_{2}$ load in the atmosphere.

\subsection{CO Observations over RSA and Gauteng Province}

Fig. 6 shows the distribution of CO over RSA before and during the lockdown, indicating large $\mathrm{CO}$ distributions and high $\mathrm{CO}$ column density values $\left(0.026 \mathrm{~mol} \mathrm{~m}^{-2}\right)$ in the north-eastern parts of RSA (Limpopo Province). High CO column density values $\left(0.03 \mathrm{~mol} \mathrm{~m}^{-2}\right)$ are also observed at the RSA and Zimbabwe border. This may be due to exhaust vehicle emissions (mainly from trucks) that pass the Beitbridge Border daily, i.e., one of the busiest borders in Southern Africa. This 


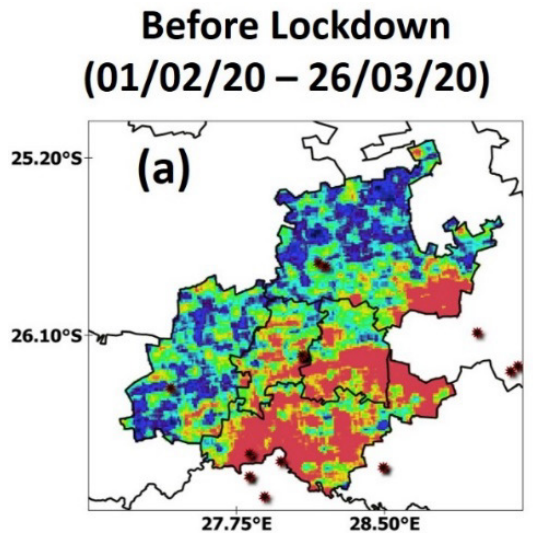

Level 4 Lockdown

(01/05/20 - 31/05/20)

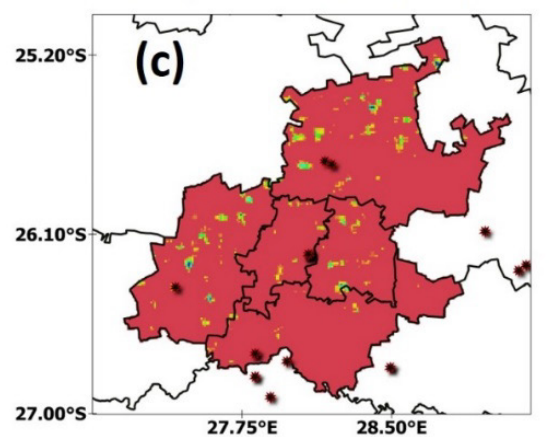

Level 5 Lockdown

(27/03/20 - 30/04/20)

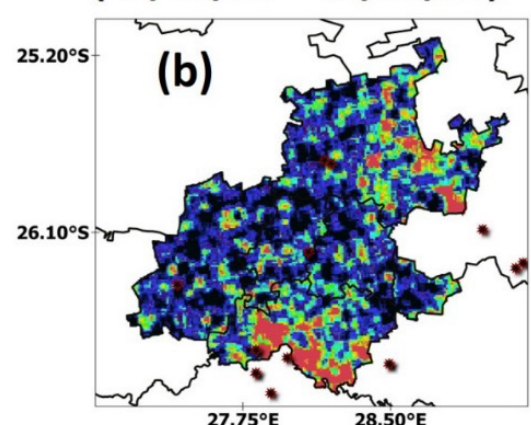

South Africa power stations

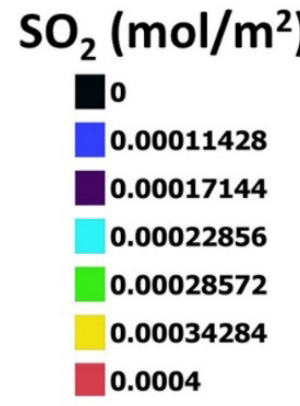

Fig. 5. $\mathrm{SO}_{2}$ total column density and distribution (a) before the lockdown, (b) during the lockdown Level 5 and (c) during the lockdown Level 4 over the Gauteng Province.

Before Lockdown

(01/02/20 - 26/03/20)

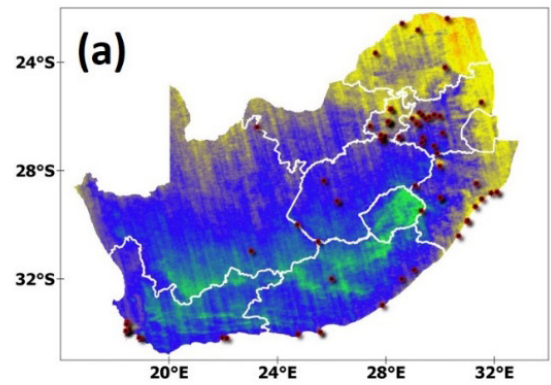

Level 4 Lockdown $(01 / 05 / 20-31 / 05 / 20)$

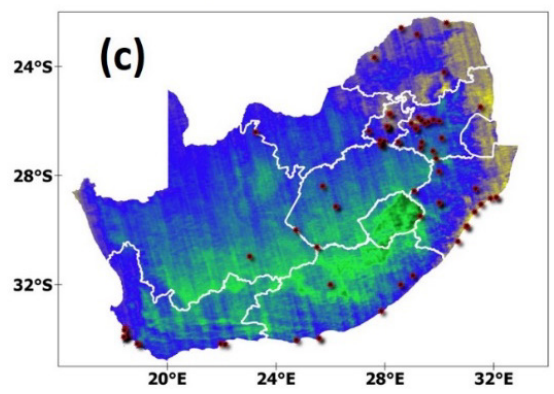

Level 5 Lockdown

$(27 / 03 / 20-30 / 04 / 20)$

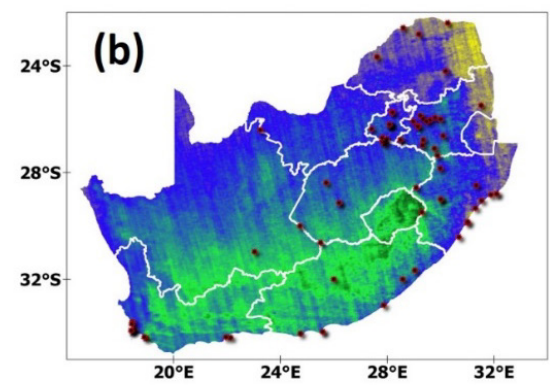

South Africa power stations

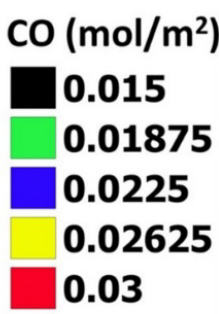

Fig. 6. CO total column density and distribution (a) before the lockdown, (b) during the lockdown Level 5 and (c) during the lockdown Level 4 over RSA. 
results in a large injection of $\mathrm{CO}$ into the atmosphere. The Lebombo Border between RSA and Mozambique also sees large amounts of $\mathrm{CO}$ for the same reason. Because of its high traffic congestions and industries, the Gauteng Province also shows high amounts of CO column density. The interior, southern and western parts of RSA have lesser amounts of CO column density values $\left(0.0023 \mathrm{~mol} \mathrm{~m}^{-2}\right)$. This is primarily because of the absence of high traffic congestions and fewer operational industries. During the Level-5 lockdown (see Fig. 6(b)), these areas saw a further drop of $\sim 17 \%$ in CO column density. Similar results are observed in the Gauteng Province and the borders of Zimbabwe and Mozambique. The decrease in CO emissions was due to the limited cross border movements imposed by the RSA government. Only limited trucks carrying goods regarded as essential were allowed to cross the borders. The easing of restrictions to Level-4 lockdown (see Fig. 6(c)) allowed for more trucks across the border and a country as a whole. Nevertheless, this does not have a significant impact on the CO column density across the country. No significant changes are observed in the Level- 4 and Level- 5 CO distributions.

The Gauteng Province $\mathrm{CO}$ distribution before and during the lockdown is seen in Fig. 7. Before the lockdown (see Fig. 7(a)), high CO column density values $\left(0.026 \mathrm{~mol} \mathrm{~m}^{-2}\right)$ are observed in Johannesburg, Ekurhuleni, and Tshwane municipalities. These are urban areas with high traffic congestions. Therefore, high values of $\mathrm{CO}$ in these are mainly from exhaust vehicle emissions. Moreover, industries and informal settlements might also contribute to the high CO column density (Shikwambana and Tsoeleng, 2020). During the Level-5 lockdown (see Fig. 7(b)), most of Gauteng had a $\sim 14 \%$ decrease in CO column density. This is due to lesser vehicles on the road and many industries' closing due to the RSA lockdown regulations. With the easing of the lockdown regulations to Level-4, a slight increase in CO distribution is observed (see Fig. 7(c)). This $\mathrm{CO}$ could be from an increase in the number of vehicles on the road and partial openings of Gauteng industries.
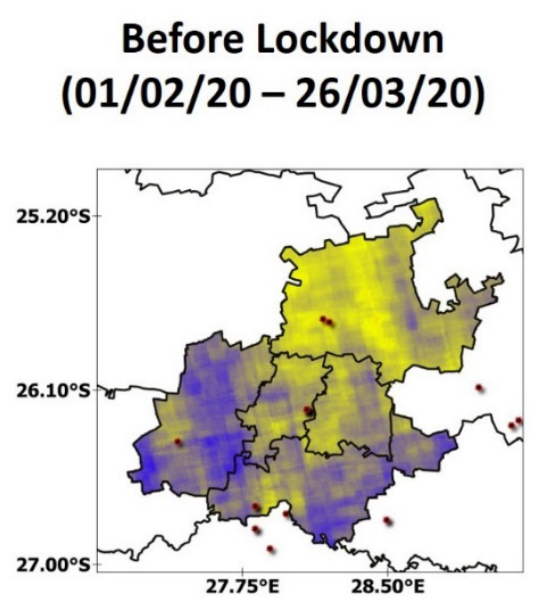

Level 4 Lockdown
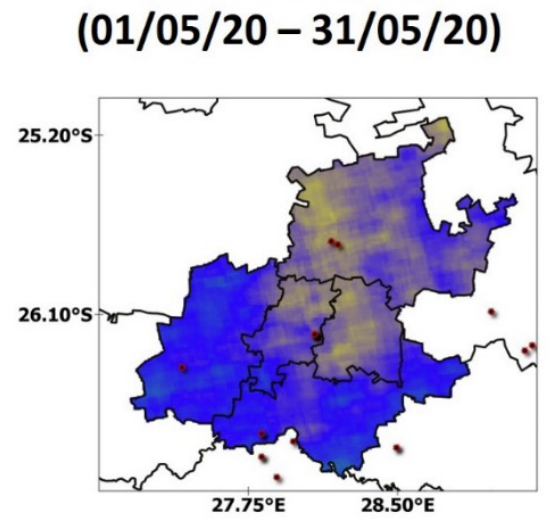

\section{Level 5 Lockdown $(27 / 03 / 20-30 / 04 / 20)$}

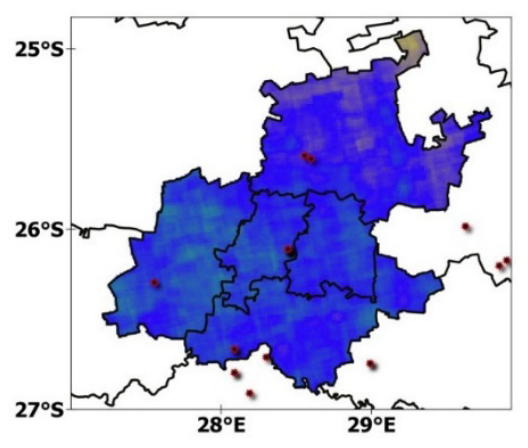

\section{South Africa power stations}

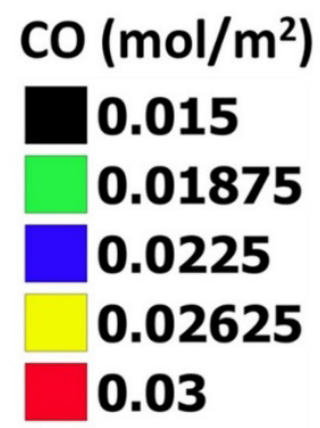

Fig. 7. CO total column density and distribution (a) before the lockdown, (b) during the lockdown Level 5 and (c) during the lockdown Level 4 over the Gauteng Province. 


\subsection{LST and Surface Urban Heat Islands}

Fig. 8 shows the LST results for Gauteng Province and its surroundings for 2020 (i.e., COVID-19 year) and 2019 (i.e., reference year) and the LST differences between these years. Specifically, LST was averaged over various periods: 01 February-26 March, 27 March-30 April, and 01-31 May, characterising periods before lockdown, during Level-5 lockdown and Level-4 lockdown, respectively. Generally, the results show that the LST for COVID-19 year, i.e., 2020, was slightly higher than the reference year, i.e., 2019, depicted by widely distributed LST differences around $0.7^{\circ} \mathrm{C}$ over the study area (see Table 2), especially before the lockdown restrictions (i.e., 01 February-26 March) and during Level-5 lockdown (27 March-30 April). However, the results also show fewer areas showing the lower LST between the years. In particular, the eastern part of the province (i.e., east of Tshwane and Lesedi) shows lower LST (i.e., the difference of around $-3.7^{\circ} \mathrm{C}$ ) during Level-5 lockdown. These areas correspond to cultivated and grassland land covers
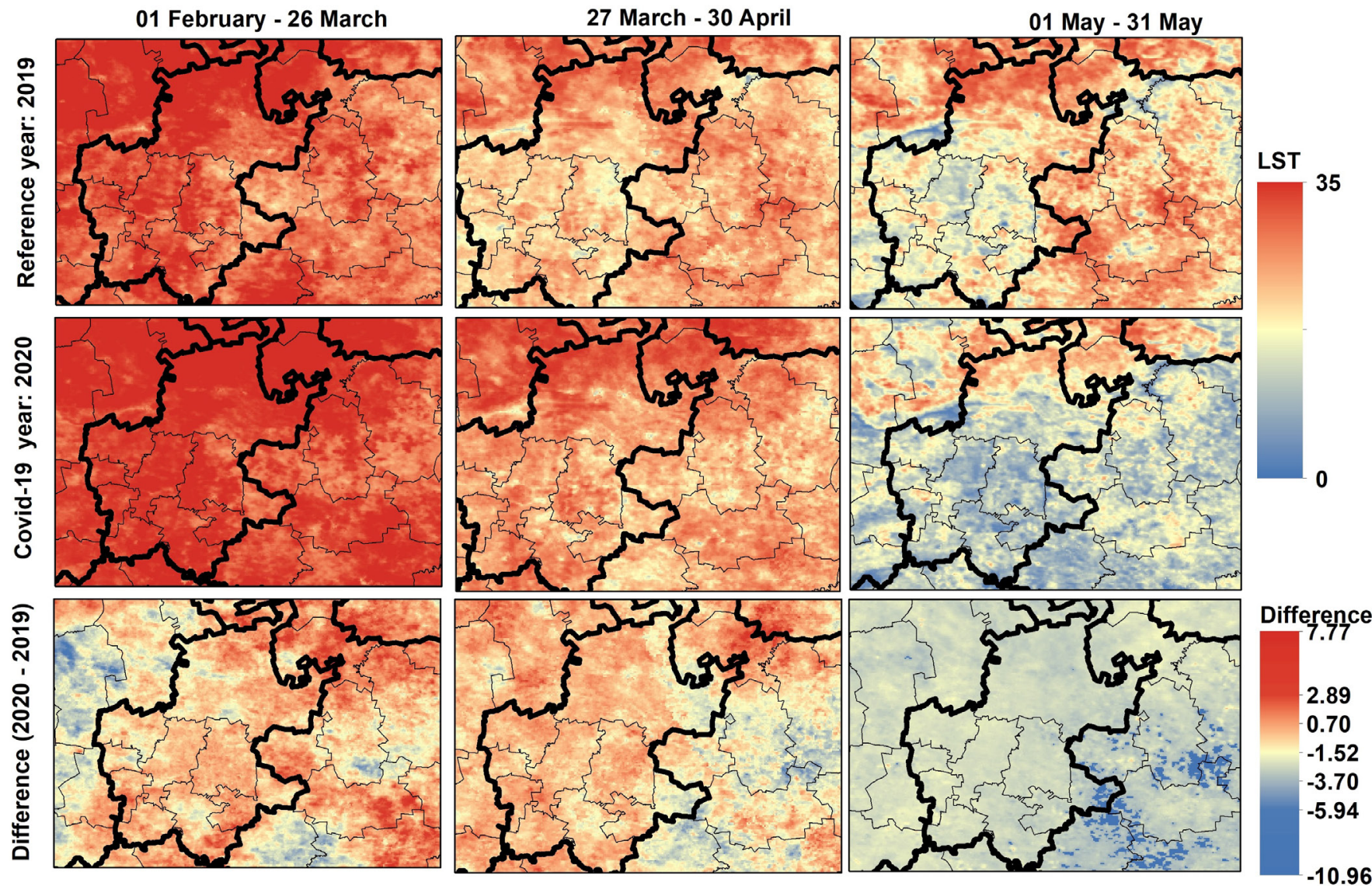

Fig. 8. LST over the Gauteng Province before and during the lockdown and LST differences between COVID-19 year (2019) and reference year (2019).

Table 2. Descriptive statistics for LST at periods: February 01-March 26; March 27-April 30; and May 01-May 31.

\begin{tabular}{ccccc}
\hline LST (C) & Mean & S.D. & Min. & Max. \\
\hline Reference year (2019) & & & & \\
01 Feb-26 March & 29.82 & 1.72 & 23.48 & 36.36 \\
27 March-30 April & 25.33 & 1.24 & 20.30 & 29.85 \\
01 May-31 May & 24.35 & 1.29 & 18.15 & 28.55 \\
COVID-19 year (2020) & & & & \\
01 Feb-26 March & 29.78 & 1.75 & 23.49 & 35.58 \\
27 March-30 April & 25.07 & 1.29 & 19.43 & 29.91 \\
01 May-31 May & 21.97 & 1.12 & 16.79 & 25.80 \\
\hline
\end{tabular}


(see Fig. 1). On the other hand, markedly low LST values in 2020 relative to 2019 are observed during Level-4 lockdown across the study area. However, the northern part of the study area (i.e., Tshwane) has higher LST than other areas. This area is characterized by Forested land, grasslands, and built-up areas (see Fig. 1) as well as the rapid proliferation of informal settlements. It is anticipated that the land clearance in the construction of settlements may have resulted in the observed high LST values during the 01-30 May period. Feng et al. (2019) found that bare soil is an intense heat source, thus agrees with our results. Moreover, previous studies (Luyssaert et al., 2014; Fu and Weng, 2016; Ravanelli et al., 2018) note that LST is closely related to land-use patterns and configuration, coverage, and landscape structure. Nevertheless, the SDI results indicate no significant difference between 2020 (i.e., COVID-19) and 2019 (i.e., reference year) for all dates considered, i.e., 01 February-26 March (i.e., SDI = -0.01); 27 March-30 April (i.e., $\mathrm{SDI}=-0.1$ ); and 01 May-31 May (i.e., SDI = -0.99), respectively.

The surface urban heat island (SUHI) intensity (Fig. 9) indicates high intensity $\left(\sim 3^{\circ} \mathrm{C}\right.$ ) in northern Gauteng province (i.e., Tshwane), driven by a myriad of factors including Urban expansion due to proliferation of informal settlements and agricultural land clearance. The areas in the middle and southern interior of the province such as Johannesburg, Ekurhuleni, Emfuleni and Midvaal also exhibit high SUHI intensity. These areas are mainly built-up, characterized by commercial and residential buildings and mining areas. Comparatively and in agreement with LST results, the SUHI intensity during 01 February-26 March period is more or less similar to the reference year (i.e., 2019), while it is lower (i.e., $\sim-3^{\circ} \mathrm{C}$ ) in the eastern part of the province (i.e., east of Tswane and Lesedi) during Level-5 lockdown (i.e., 27 March-30 April) and most of the interior during Level-4 lockdown (01-31 May). As shown earlier the decline in electricity production, minimal industry operations, and lesser motor vehicles on the road are responsible for the decrease in emissions $\left(\mathrm{NO}_{2}\right.$ and $\left.\mathrm{CO}\right)$ in the province. These emissions are known to cause anthropogenic heating, which substantially raises the temperatures. However, there was no evidence of the influence of these emissions on LST and SUHI in this study. Therefore, this aspect as well as other
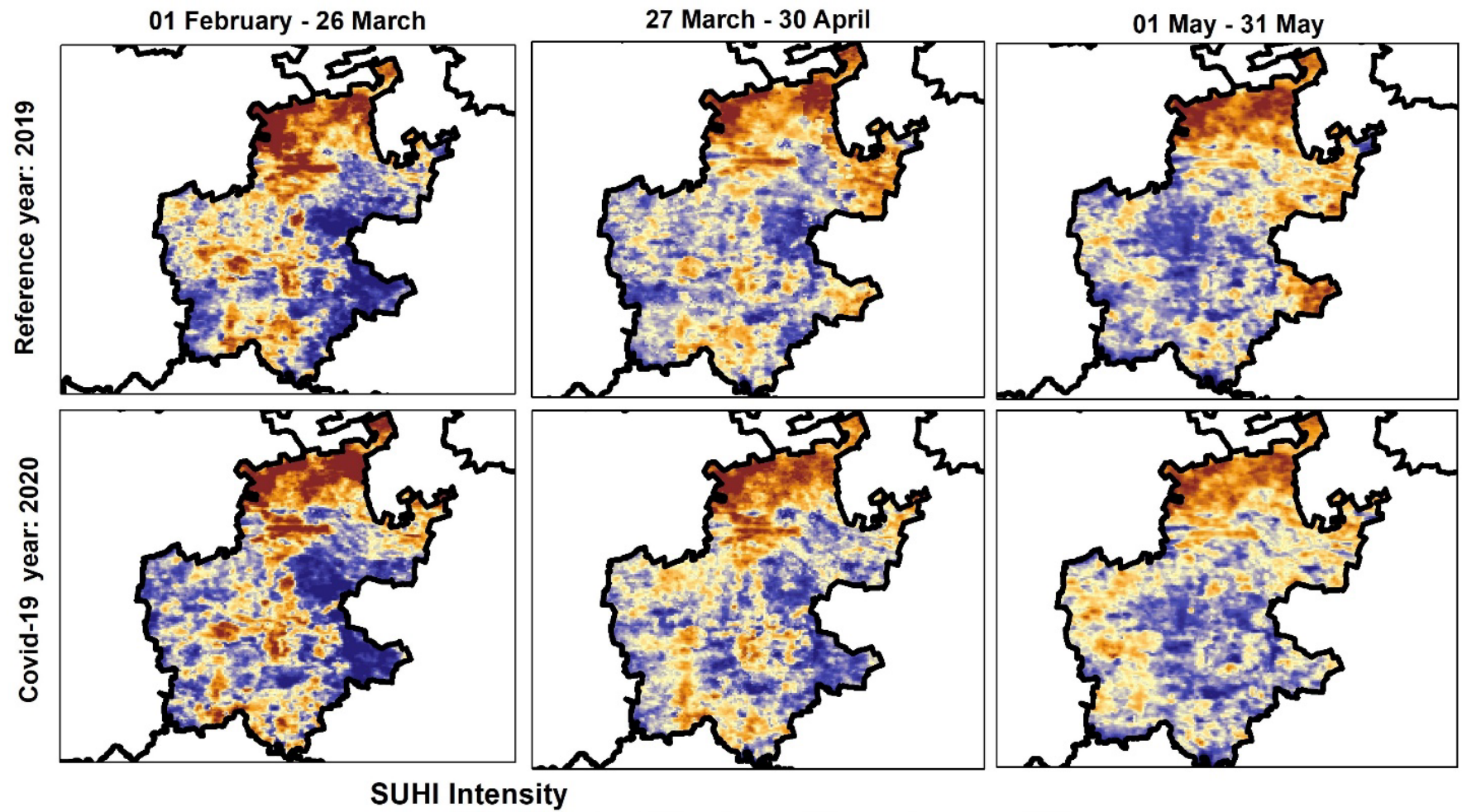

\section{SUHI Intensity}

High : 3

Low : -3

Fig. 9. Surface urban heat island (SUHI) intensity before (01 February-26 March), during Level-5 lockdown (27 March-30 April) and level-4 (01-31 May). 
influencing factors of SUHI and LST such as land-use patterns and topography need to be investigated further in the future, to reveal the effect of COVID-19 Lockdown emission reductions on anthropogenic heating. The observed slight decline in LST and SUHI, in this study, is mainly attributed to the expected to drop in temperature from February to May due to a change in season (i.e., from summer to autumn).

\subsection{Trend analysis of $\mathrm{SO}_{4}$, LWR and LST}

Mann-Kendall (M-K) trend test is applied to determine whether there is a significant trend in the surface absorbed long-wave radiation (LWR) and sulfate $\left(\mathrm{SO}_{4}\right)$ concentration in Gauteng Province (see Table 3). The null hypothesis $\left(\mathrm{H}_{0}\right)$ that there is no significant trend in the LWR and $\mathrm{SO}_{4}$ at $95 \%$ confidence level $(\alpha=0.05)$ was tested. The LWR results show a significant increasing trend for 2018 and decreasing significant trends for 2019 and 2020. SO 4 results show significantly decreasing trends for 2018-2020.

The SQMK test is further applied to the $\mathrm{SO}_{4}$ concentration for the period 2018-2020 (for the months, February-May only) over Gauteng Province. The trend of the $\mathrm{SO}_{4}$ concentration for the three years is shown in Fig. 10(a). In the 2018 period, the highest peak concentration of $\mathrm{SO}_{4}$ is observed in the early days of April, and a subsequent stable decrease in $\mathrm{SO}_{4}$ concentration until May is observed. On the other hand, in the March-May 2019 period, a steady trend with less variations is observed. However, during the lockdown period of April-May 2020, a decreasing trend in $\mathrm{SO}_{4}$ concentration is observed. The main emissions of $\mathrm{SO}_{4}$ include coal-fired power stations (Shikwambana and Sivakumar, 2019), diesel-powered light-duty vehicles (Truex et al., 1980), and diesel-powered machinery. Therefore, the decline in $\mathrm{SO}_{4}$ concentration during the Level-5 and Level-4 lockdown in Gauteng (see Fig. 10(b)) can be attributed to a drop in the operation of the coal power station (due to less electricity demand) and a reduction in motor vehicles on the road.

The SQMK test on the LST does not show any significant trend (see Fig. 11(a)). Therefore, based on this result, it is difficult to determine the behaviour of LST during the lockdown period. In

Table 3. M-K test results for $\mathrm{LWR}$ and $\mathrm{SO}_{4}$ over three years, i.e., 2018, 2019, and 2020. Positive $\mathrm{M}-\mathrm{K}$ tau value indicates an increasing trend, while the negative values indicate a decreasing trend.

\begin{tabular}{llllll}
\hline \multirow{2}{*}{ Parameter } & \multicolumn{2}{c}{ Longwave Radiation (LWR) } & & \multicolumn{2}{c}{$\mathrm{SO}_{4}$} \\
\cline { 2 - 3 } & $\mathrm{Tau}(\tau)$ & $p$-value & & Tau $(\tau)$ & $p$-value \\
\hline 2018 & 0.857 & 0.004434 & & -0.296 & $<2.22 \mathrm{e}-16$ \\
2019 & -0.285 & $<2.22 \mathrm{e}-16$ & & -0.273 & $<2.22 \mathrm{e}-16$ \\
2020 & -0.284 & $<2.22 \mathrm{e}-16$ & & -0.284 & $<2.22 \mathrm{e}-16$ \\
\hline
\end{tabular}

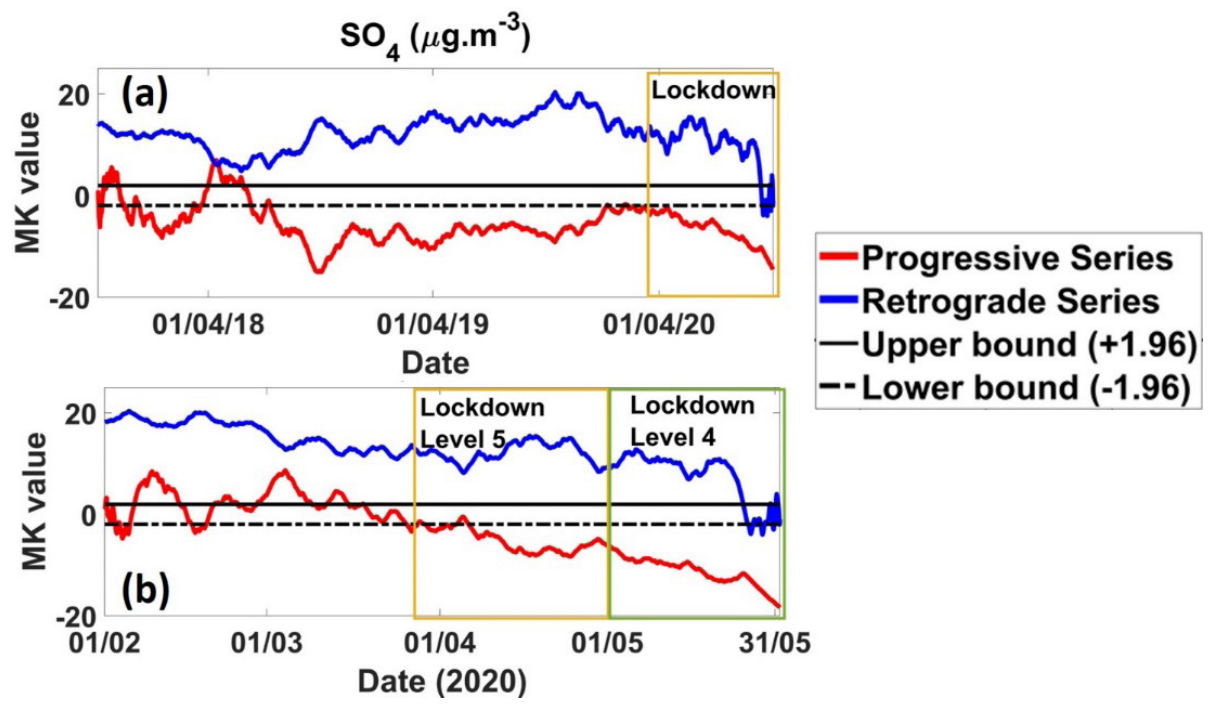

Fig. 10. Sequential Mann-Kendall trend for $\mathrm{SO}_{4}$ during (a) 2018-2020 and (b) 2020. 


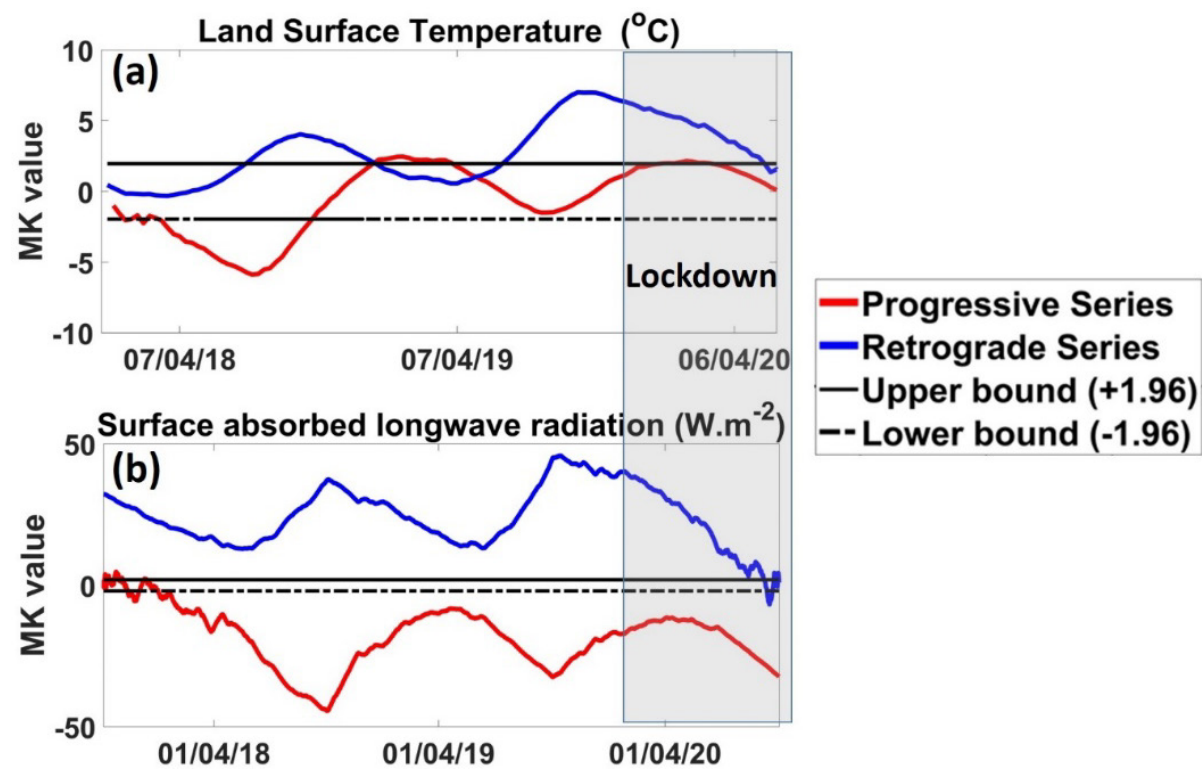

Fig. 11. Sequential Mann-Kendall trend during for the period 2018-2020 for (a) LST and (b) LWR.

contrast, LWR shows a decreasing trend during the lockdown period (see Fig. 11(b)), which agrees with Table 2. However, this type of decrease is also seen in the years 2018 and 2019. This seasonal decrease in LWR is due to various factors such as Earth's skin temperature, surface emissivity, atmospheric temperature, water vapour profile, and cloud cover. Therefore, a quantitative study is required to determine the effect of the lockdown on the LWR.

\section{CONCLUSIONS}

Globally, the COVID-19 pandemic has adversely impacted socio-economic activities. The spread of the disease has left many destitute, especially in Africa. The lockdown restrictions in many African countries, including RSA, has led to many companies permanently closing down due to financial difficulties. Nevertheless, the slowing down of the economic activities in RSA has led to an improvement in air quality. During the Level-5 lockdown, most industries and mines were closed. The number of motor vehicles on the road reduced, and the coal-fired power stations' operations were reduced drastically due to a lack of electricity demand by industries. Indeed, the nation-wide lockdown restrictions have positively impacted air quality, human health, and the environment. Atmospheric gases such as $\mathrm{SO}_{2}, \mathrm{NO}_{2}$, and $\mathrm{CO}$ are toxic, especially to human populations living in cities where there are vast sources. Therefore, as observed in this study, the lockdown restrictions have led to a brief decline in emissions, highlighting the effect of human activities on the environment.

Moreover, LST and SUHI from MODIS showed slight reductions over some parts of the province during period consistent with the imposed lockdown regulations. It is, however, not clear whether the observed reductions in $\mathrm{SO}_{2}, \mathrm{NO}_{2}$, and $\mathrm{CO}$ emissions were the cause of the decline in LST and SUHI, as the period under study coincides with normal cooling as seasons change. Therefore, this aspect needs a more in-depth analysis in future studies. Overall, the results in this study provide insights into the effect of policy changes on emissions and the potential in reducing the effect on micro-climates and related human health risks.

\section{ACKNOWLEDGMENTS}

The authors wish to thank the South African National Space Agency and the University of the Witwatersrand for their support in this study. We gratefully acknowledge ESA for the Sentinel$5 \mathrm{P} /$ TROPOMI products. We acknowledge the GES-DISC Interactive Online Visualization and Analysis Infrastructure (Giovanni) for providing us with the MERRA-2 and OMI data. The authors 
would also like to thank the National Aeronautics and Space Administration (NASA) for their support in LST data.

\section{DISCLAIMER}

The authors declare that there are no financial and personal interests that influenced the results and work presented in the manuscript.

\section{SUPPLEMENTARY MATERIAL}

Supplementary material for this article can be found in the online version at https://doi. org/10.4209/aaqr.200437

\section{REFERENCES}

Abghari, H., Tabari, H., Talaee, P.H. (2013). River flow trends in the west of iran during the past 40 years, Impact of precipitation variability. Global Planet. Change 101, 52-60. https://doi.org/ 10.1016/j.gloplacha.2012.12.003

Arifwidodo, S., Chandrasiri, O. (2015). Urban heat island and household energy consumption in Bangkok, Thailand. Energy Procedia 79, 189-194. https://doi.org/10.1016/j.egypro.2015.11.461

Azevedo, J.A., Chapman, L., Muller, C.L. (2016). Quantifying the day-time and night-time urban heat island in Birmingham, UK: A comparison of satellite derived land surface temperature and high resolution air temperature observations. Remote Sens. 8, 153. https://doi.org/10.3390/r s8020153

Beach, B., Clay, K., Saavedra, M.H. (2020). The 1918 influenza pandemic and its lessons for COVID19. National Bureau of Economic Research. https://doi.org/10.3386/w2767

Buchard, V., Randles, C., Da Silva, A., Darmenov, A., Colarco, P., Govindaraju, R., Ferrare, R., Hair, J., Beyersdorf, A., Ziemba, L. (2017). The MERRA-2 aerosol reanalysis, 1980 onward. Part II: Evaluation and case studies. J. Clim. 30, 6851-6872. https://doi.org/10.1175/JCLI-D-16-0613.1

Chen, X.L., Zhao, H.M., Li, P.X., Yin, Z.Y. (2006). Remote sensing image-based analysis of the relationship between urban heat island and land use/cover changes. Remote Sens. Environ. 104, 133-146. https://doi.org/10.1016/j.rse.2005.11.016

Energy Transition In South Africa - The Power Sector in 2020 (2020). https://www.fticonsultinglatam.com/ /media/Files/emea--files/insights/reports/2020/dec/energy-transition-southafrica-power-sector-2020.pdf (accessed 18 February 2021).

Estoque, R.C., Murayama, Y. M. (2017). Monitoring surface urban heat island formation in a tropical mountain city using Landsat data (1987-2015). ISPRS J. Photogramm. Remote Sens. 133, 18-29. https://doi.org/10.1016/j.isprsjprs.2017.09.008

Fairbanks, D.H.K., Thompson, M.W., Vink, D.E., Newby, T.S., Van den Berg, H.M., Everard D.A. (2000). The South African Land-cover Characteristics Database: A synopsis of the landscape. S. Afr. J. Sci. 96, 69-82. https://doi.org/10.10520/AJA00382353_7429

Feng, Y., Du, S., Myint, S.W., Shu, M. (2019). Do urban functional zones affect land surface temperature differently? A case study of Beijing, China. Remote Sens. 11, 1802. https://doi.org/ $10.3390 /$ rs11151802

Fu, P., Weng, Q. (2016). A time series analysis of urbanisation induced land use and land cover change and its impact on land surface temperature with landsat imagery. Remote Sens. Environ. 175, 205-214. https://doi.org/10.1016/j.rse.2015.12.040

Gallo, K., McNab, A., Karl, T.R., Brown, J.F., Hood, J., Tarpley, J. (1993). The use of a vegetation index for assessment of the urban heat island effect. Remote Sens. 14, 2223-2230. https://doi.org/10.1080/01431169308954031

Gao, H., Fu, R., Dickinson, R.E., Juárez, R.I.N. (2007). A practical method for retrieving land surface temperature from AMSR-E over the amazon forest. IEEE Trans. Geosci. Remote Sens. 46, 193199. https://doi.org/10.1109/TGRS.2007.906478

Gelaro, R., McCarty, W., Suárez, M.J., Todling, R., Molod, A., Takacs, L., Randles, C.A., Darmenov, 
A., Bosilovich, M.G., Reichle, R. (2017). The Modern Era Retrospective analysis for Research and Applications Version 2 (MERRA-2). J. Clim. 30, 5419-5454. https://doi.org/10.1175/JCLID-16-0758.1

Girmay, M.E., Chikobvu, D. (2017). Quantifying South Africa's sulphur dioxide emission efficiency in coal-powered electricity generation by fitting the three-parameter log-logistic distribution. J. Energy South. Afr. 28, 91-103. https://doi.org/10.17159/2413-3051/2017/v28i1a1530

Grimmond, S.U. (2007). Urbanisation and global environmental change, Local effects of urban warming. Geog. J. 173, 83-88. https://doi.org/10.1111/j.1475-4959.2007.232_3.x

Haldar, A., Sethi, N. (2020). The effect of country-level factors and government intervention on the incidence of COVID-19. Asian Econ. Lett. 1, 17804. https://doi.org/10.46557/001c.17804

Harapan, H., Itoh, N., Yufika, A., Winardi, W., Keam, S., Te, H., Megawati, D., Hayati, Z., Wagner, A.L., Mudatsir, M. (2020). Coronavirus disease 2019 (COVID-19): A literature review. J. Infect. Public Health 13, 667-673. https://doi.org/10.1016/j.jiph.2020.03.019

Hifumi, T., Kondo, Y., Shimizu, K., Miyake, Y. (2018). Heat stroke. J. Intensive Care 6, 30. https://doi.org/10.1186/s40560-018-0298-4

Ialongo, I., Virta, H., Eskes, H., Hovila, J., Douros, J. (2020). Comparison of TROPOMI/Sentinel-5 Precursor $\mathrm{NO}_{2}$ observations with ground-based measurements in Helsinki. Atmos. Meas. Tech. 13, 205-218. https://doi.org/10.5194/amt-13-205-2020

Jain, S., Sharma, T. (2020). Social and travel lockdown impact considering coronavirus disease (COVID-19) on air quality in megacities of India: Present benefits, future challenges and way forward. Aerosol Air Qual. Res. 20, 1222-1236. https://doi.org/10.4209/aaqr.2020.04.0171

Kganyago, M., Odindi, J., Adjorlolo, C., Mhangara, P. (2018). Evaluating the capability of Landsat $8 \mathrm{OLI}$ and SPOT 6 for discriminating invasive alien species in the African Savanna landscape. Int. J. Appl. Earth Obs. Geoinf. 67, 10-19. https://doi.org/10.1016/j.jag.2017.12.008

Kganyago, M., Shikwambana, L. (2019). Assessing spatio-temporal variability of wildfires and their impact on sub-saharan ecosystems and air quality using multisource remotely sensed data and trend analysis. Sustainability 11, 6811. https://doi.org/10.3390/su11236811

Levelt, P.F., van den Oord, G.H.J., Dobber, M.R., Mälkki, A., Visser, H., de Vries, J., Stammes, P. Lundell, J.O.V., Saari, H. (2006). The ozone monitoring instrument. IEEE Trans. Geosci. Remote Sens. 44, 1093-1101. https://doi.org/10.1109/TGRS.2006.872333

Leyk, D., Hoitz, J., Becker, C., Glitz, K.J., Nestler, K., Piekarski, C. (2019). Health risks and interventions in exertional heat stress. Dtsch. Arztebl. Int. 116, 537-544. https://doi.org/10.32 38/arztebl.2019.0537

Liu, L., Zhang, Y. (2011). Urban heat island analysis using the landsat TM data and ASTER data: A case study in Hong Kong. Remote Sens. 3, 1535-1552. https://doi.org/10.3390/rs3071535

Luyssaert, S., Jammet, M., Stoy, P.C., Estel, S., Pongratz, J., Ceschia, E., Churkina, G., Don, A., Erb, K., Ferlicoq, M., Gielen, B., Grünwald, T., Houghton, R.A., Klumpp, K., Knohl, A., Kolb, T., Kuemmerle, T., Laurila, T., Lohila, A., Loustau, D., et al. (2014). Land management and landcover change have impacts of similar magnitude on surface temperature. Nat. Clim. Change 4, 389-393. https://doi.org/10.1038/nclimate2196

Ma, S., Pitman, A., Hart, M., Evans, J.P., Haghdadi, N., MacGill, I. (2017). The impact of an urban canopy and anthropogenic heat fluxes on Sydney's climate. Int. J. Climatol. 37, 255-270. https://doi.org/10.1002/joc.5001

Mann, H.B. (1945). Non-parametric tests against trend. Econometrica 13, 245-259. https://doi.org/10.2307/1907187

Metya, A., Dagupta, P., Halder, S., Chakraborty, S., Tiwari, Y.K. (2020). COVID-19 lockdowns improve air quality in the south-east Asian regions, as seen by the remote sensing satellites. Aerosol Air Qual. Res. 20, 1772-1782. https://doi.org/10.4209/aaqr.2020.05.0240

Mosmann, V., Castro, A., Fraile, R., Dessens, J., Sanchez, J. (2004). Detection of statistically significant trends in the summer precipitation of mainland Spain. Atmos. Res. 70, 43-53. https://doi.org/10.1016/j.atmosres.2003.11.002

Nashwan, M.S., Shahid, S. (2019). Spatial distribution of unidirectional trends in climate and weather extremes in Nile river basin. Theor. Appl. Climatol. 137, 1181-1199. https://doi.org/1 0.1007/s00704-018-2664-5

Oke, T.R. (1982). The energetic basis of the urban heat island. Q. J. R. Meteorolog. Soc. 108, 124. https://doi.org/10.1002/qj.49710845502 
Oke, T.R. (1988). The urban energy balance. Prog. Phys. Geogr. 12, 471-508. https://doi.org/10.1 177/030913338801200401

Omrani, H., Omrani, B., Parmentier, B., Helbich, M. (2020). Spatio-temporal data on the air pollutant nitrogen dioxide derived from Sentinel satellite for France. Data Brief 28, 105089. https://doi.org/10.1016/j.dib.2019.105089

Pierson, W., Brachaczek, W., Hammerle, R., McKee, D., Butler, J. (1978). Sulfate emissions from vehicles on the road. J. Air Pollut. Control Assoc. 28, 123-132. https://doi.org/10.1080/00022 470.1978.10470579

Pohlert, T. (2018). trend: Non-Parametric Trend Tests and Change-Point Detection. R package version 1. https://cran.r-project.org/web/packages/trend/vignettes/trend.pdf (accessed 8 July 2021).

Pretorius, I., Piketh, S., Burger, R., Neomagus, H. (2015). A perspective on South African coal fired power station emissions. J Energy South Afr. 26, 27-40. https://doi.org/10.17159/24133051/2015/v26i3a2127

Priyadarsini, R. (2009). Urban heat island and its impact on building energy consumption. Adv. Build. Energy Res. 3, 261-270. https://doi.org/10.3763/aber.2009.0310

Ramanathan, V., Feng, Y. (2009). Air pollution, greenhouse gases and climate change, Global and regional perspectives. Atmos. Environ. 43, 37-50. https://doi.org/10.1016/j.atmosenv.2008.0 9.063

Randles, C., Da Silva, A., Buchard, V., Colarco, P., Darmenov, A., Govindaraju, R., Smirnov, A., Holben, B., Ferrare, R., Hair, J. (2017). The MERRA-2 aerosol reanalysis, 1980 onward. Part I: System description and data assimilation evaluation. J. Clim. 30, 6823-6850. https://doi.org/1 0.1175/JCLI-D-16-0609.1

Ravanelli, R., Nascetti, A., Cirigliano, R.V., Di Rico, C., Leuzzi, G., Monti, P., Crespi, M. (2018). Monitoring the impact of land cover change on surface urban heat island through Google Earth Engine: Proposal of a global methodology, first applications and problems. Remote Sens. 10, 1488. https://doi.org/10.3390/rs10091488

Rienecker, M.M., Suarez, M., Todling, R., Bacmeister, J., Takacs, L., Liu, H., Gu, W., Sienkiewicz, M., Koster, R., Gelaro, R. (2008). The GEOS-5 Data Assimilation System-Documentation of Versions 5.0.1, 5.1.0, and 5.2.0. Technical Report Series on Global Modeling and Data Assimilation, NASA/TM-2008-104606, Vol. 27. National Aeronautics and Space Administration. https://gmao.gsfc.nasa.gov/pubs/docs/Rienecker369.pdf (accessed 08 July 2021).

Rienecker, M.M., Suarez, M.J., Gelaro, R., Todling, R., Bacmeister, J., Liu, E., Bosilovich, M.G., Schubert, S.D., Takacs, L., Kim, G.K. (2011). MERRA, NASA's modern-Era retrospective analysis for research and applications. J. Clim. 24, 3624-3648. https://doi.org/10.1175/JCLI-D-1100015.1

Ryu, Y.H., Baik, J.J. (2012). Quantitative analysis of factors contributing to urban heat island intensity. J. Appl. Meteorol. Climatol. 51, 842-854. https://doi.org/10.1175/JAMC-D-11-098.1

Schiano-Phan, R., Weber, F., Santamouris, M. (2015). The mitigative potential of urban environments and their microclimates. Buildings 5, 783-801. https://doi.org/10.3390/building s5030783

Şen, Z. (2017). Innovative trend significance test and applications. Theor. Appl. Climatol. 127, 939-947. https://doi.org/10.1007/s00704-015-1681-x

Shahmohamadi, P., Che-Ani, A., Maulud, K., Tawil, N.M., Abdullah, N. (2011). The impact of anthropogenic heat on formation of urban heat island and energy consumption balance. Urban Stud. Res. 2011, 497524. https://doi.org/10.1155/2011/497524

Shi, Y., Xiang, Y., Zhang, Y. (2019). Urban design factors influencing surface urban heat island in the high-density city of Guangzhou based on the local climate zone. Sensors 19, 3459. https://doi.org/10.3390/s19163459

Shikwambana, L., Sivakumar, V. (2019). Investigation of various aerosols over different locations in South Africa using satellite, model simulations and LIDAR. Meteorol. Appl. 26, 275-287. https://doi.org/10.1002/met.1761

Shikwambana, L., Mhangara, P., Mbatha, N. (2020). Trend analysis and first time observations of sulphur dioxide and nitrogen dioxide in South Africa using TROPOMI/Sentinel-5 P data. Int. J. Appl. Earth Obs. Geoinf. 91, 102130. https://doi.org/10.1016/j.jag.2020.102130

Shikwambana, L., Tsoeleng, L.T. (2020). Impacts of population growth and land use on air quality. 
A case study of Tshwane, Rustenburg and Emalahleni, South Africa. S. Afr. Geog. J. 102, 209222. https://doi.org/10.1080/03736245.2019.1670234

Sneyers, R. (1990). On the statistical analysis of series of observations World Meteorological Organization (WMO). Technical note No. 143, Geneva, 192.

Sneyers, R. (1997). Climate chaotic instability, Statistical determination and theoretical background. Environmetrics 8, 517-532. https://doi.org/10.1002/(SICI)1099-095X(199709/10)8:5<517::AIDENV267>3.0.CO;2-L

Soltani, A., Sharifi, E. (2017). Daily variation of urban heat island effect and its correlations to urban greenery: A case study of Adelaide. Front. Archit. Res. 6, 529-538. https://doi.org/10.10 16/j.foar.2017.08.001

Sonali, P., Kumar, D.N. (2013). Review of trend detection methods and their application to detect temperature changes in India. J. Hydrol. 476, 212-227. https://doi.org/10.1016/j.jhydrol.2012. 10.034

Suomi, J. (2018). Extreme temperature differences in the city of Lahti, southern Finland: Intensity, seasonality and environmental drivers. Weather Clim. Extremes 19, 20-28. https://doi.org/10. 1016/j.wace.2017.12.001

Tabari, H., Marofi, S., Aeini, A., Talaee, P.H., Mohammadi, K. (2011). Trend analysis of reference evapotranspiration in the western half of Iran. Agric. For. Meteorol. 151, 128-136. https://doi.org/10.1016/j.agrformet.2010.09.009

Taha, H. (1997). Urban climates and heat islands, Albedo, evapotranspiration, and anthropogenic heat. Energy Build 25, 99-103. https://doi.org/10.1016/S0378-7788(96)00999-1

Theys, N., Hedelt, P., De Smedt, I., Lerot, C., Yu, H., Vlietinck, J., Pedergnana, M., Arellano, S., Galle, B., Fernandez, D. (2019). Global monitoring of volcanic $\mathrm{SO}_{2}$ degassing with unprecedented resolution from TROPOMI onboard Sentinel-5 Precursor. Sci. Rep. 9, 2643. https://doi.org/10.1038/s41598-019-39279-y

Theys, N., Smedt, I.D., Yu, H., Danckaert, T., Gent, J.v., Hörmann, C., Wagner, T., Hedelt, P., Bauer, H., Romahn, F. (2017). Sulfur dioxide retrievals from TROPOMI onboard Sentinel-5 Precursor: algorithm theoretical basis. Atmos. Meas. Tech. 10, 119-153. https://doi.org/10.5194/amt-10119-2017

Truex, T.J., Pierson, W.R., McKee, D.E. (1980). Sulfate in diesel exhaust. Environ. Sci. Technol. 14, 1118-1121. https://doi.org/10.1021/es60169a013

Tsou, J., Zhuang, J., Li, Y., Zhang, Y. (2017). Urban heat island assessment using the Landsat 8 data: A case study in Shenzhen and Hong Kong. Urban Sci. 1, 10. https://doi.org/10.3390/urban sci1010010

Veefkind, J., Aben, I., McMullan, K., Förster, H., De Vries, J., Otter, G., Claas, J., Eskes, H., De Haan, J., Kleipool, Q. (2012). TROPOMI on the ESA Sentinel-5 Precursor: A GMES mission for global observations of the atmospheric composition for climate, air quality and ozone layer applications. Remote Sens. Environ. 120, 70-83. https://doi.org/10.1016/j.rse.2011.09.027

Wan, Z. (2014). New refinements and validation of the collection-6 MODIS land-surface temperature/emissivity product. Remote Sens. Environ. 140, 36-45. https://doi.org/10.1016/ j.rse.2013.08.027

Wang, Y., Li, Y., Di Sabatino, S., Martilli, A, Chan, P. (2018). Effects of anthropogenic heat due to air-conditioning systems on an extreme high temperature event in Hong Kong. Environ. Res. Lett. 13, 034015. https://doi.org/10.1088/1748-9326/aaa848

Yasar, A., Haider, R., Tabinda, A.B., Kausar, F., Khan, M. (2013). A comparison of engine emissions from heavy, medium, and light vehicles for $\mathrm{cng}$, diesel, and gasoline fuels. Pol. J. Environ. Stud 22, 1277-1281.

Yu, X., Guo, X., Wu, Z. (2014). Land surface temperature retrieval from Landsat 8 TIRSComparison between radiative transfer equation-based method, split window algorithm and single channel method. Remote Sens. 6, 9829-9852. https://doi.org/10.3390/rs6109829

Zha, Y., Gao, J., Ni, S. (2003). Use of normalized difference built-up index in automatically mapping urban areas from TM imagery. Remote Sens. Lett. 24, 583-594. https://doi.org/10.1 080/01431160304987

Zhao, E., Gao, C., Jiang, X., Liu, Z. (2017). Land surface temperature retrieval from AMSR-E passive microwave data. Opt. Express 25, A940-A952. https://doi.org/10.1364/OE.25.00A940

Zhao, X., Griffin, D., Fioletov, V., McLinden, C., Cede, A., Tiefengraber, M., Müller, M., Bognar, K., 
ORIGINAL RESEARCH

Strong, K., Boersma, F., Eskes, H., Davies, J., Ogyu, A., Lee, S.C.(2020). Assessment of the quality of TROPOMI high-spatial-resolution $\mathrm{NO}_{2}$ data products in the Greater Toronto Area. Atmos Meas. Tech. 13, 2131-2159. https://doi.org/10.5194/amt-13-2131-2020 